\title{
POLARIZATION OF MACROPHAGES OF MICE UNDER THE INFLUENCE OF LECTIN FROM BACILLUS SUBTILIS IMV B-7724
}

\author{
Alina Chumak \\ Alinkaivanchenko999@ukr.net \\ Valeriia Shcherbina \\ Department of Oncohematology ${ }^{2}$ \\ l_knolodniuk@ukr.net \\ Natalia Fedosova ${ }^{1}$ \\ immunomod@ukr.net \\ Vasyl' Chekhun ${ }^{1}$ \\ chekhun@onconet.kiev.ua \\ ${ }^{1}$ Department of Monitoring of Tumor Process and Therapy Design ${ }^{2}$ \\ ${ }^{2} R$. E. Kavetsky Institute of Experimental Pathology, \\ Oncology and Radiobiology of NAS of Ukraine \\ 45 Vasylkivska str., Kyiv, Ukraine, 03022
}

\begin{abstract}
Macrophages (Mph) are highly plastic cells that are able to change their functional activity (polarization) and perform their functions in different physiological and pathological processes (including cancer). Changes in the functional activity of Mph can occur due to the action of a number of external stimuli (cytokines, colony-stimulating factors, products of microbial synthesis, etc.).

The aim of the research was to study the effect of lectin from B. subtilis IMV B-7724 on the state of macrophage polarization in intact mice of the Balb/c strain.

The cytotoxic effect of lectin from B. subtilis IMV B-7724 on the peritoneal Mph of intact Balb/c mice was evaluated in vitro; indices, characterizing the functional activity of Mph with M1 and M2 phenotypes and the levels of STAT-1 and STAT-6 mRNA expression, were determined.

We have shown that the effect of bacterial lectin on peritoneal Mph is concentration-dependent: $\geq 0.1 \mathrm{mg} / \mathrm{ml}$ is cytotoxic while 0.02 and $0.05 \mathrm{mg} / \mathrm{ml}$ is stimulating. At low concentrations of lectin there is observed a significant increase in the ratio of $\mathrm{NO}$ production to the arginase activity of Mph (NO/Arg), which is characteristic of Mph with the M1 phenotype. Changes in the expression of STAT transcription factors under the influence of the lectin were similar to the changes, found under the combined action of LPS and IFN- $\gamma$ on Mph. The detected changes in the functional activity of peritoneal Mph of intact mice under the influence of low concentrations of the lectin may be due to the changes in the expression of transcription factors of the JAK-STAT signaling pathway. Understanding the mechanisms of action of lectin from B. subtilis IMV B-7724 on Mph will open new perspectives for their modulation/polarization.
\end{abstract}

Keywords: macrophages, functional state, M1 and M2 polarization, molecular mechanisms, transcription factors.

DOI: $10.21303 / 2504-5695.2021 .001878$

\section{Introduction}

The development of new methods of therapy, aimed at improving the effectiveness of treatment of cancer patients, is the subject of many modern studies [1]. The list of substances with antitumor activity is expanding due to agents of natural origin, which exert not only cytotoxic activity, but also are able to activate the patient's immune response. The aim of immunotherapy is to restore and maintain the proper activity of the main effectors of antitumor immunity, the formation of a full-fledged immune response to tumor antigens. It is known, that antitumor immune responses play a significant role in preventing the recurrence and metastasis of the primary tumor. Therefore, the use of medicinal agents that prevent the suppression of the immune response, caused by cancer progression or the aggressive effects of chemotherapy and radiation therapy, may be effective in the complex treatment of patients $[2,3]$. 
In the study of the effectiveness of biotherapy Mph are thought to be the most promising effectors of natural immunity due to their ability to rapidly change the functional state depending on the stimuli they receive from the local microenvironment. There are Mph that have been activated by classical (M1) or alternative (M2) pathways. M1 subpopulations exert pro-inflammatory (antitumor) properties, while M2 subpopulations promote tumor growth (protumoral properties). It is a known fact that tumors are able to remodel the microenvironment and facilitate the switching M1 macrophages to the tumor-associated state. The study of M1 $\leftrightarrow$ M2 switching mechanisms and the search for possible ways to regulate the polarization process is one of the important ways for immunotherapy optimization $[4,5]$.

Activation of macrophages by the M1 pathway is mediated by the action of interferon- $\gamma$ (IFN- $\gamma$ ) and/or lipopolysaccharide (LPS) on the surface receptors IFN- $\gamma \mathrm{R}$ and/or Tolllike receptor 4 (TLR4), respectively, via the JAK-STAT signaling pathway. As a result, there is observed an increase in the expression of transcription factor (TF) STAT1 and activation of the transcription of STAT1-dependent genes. In addition, the binding of LPS to TLR4 results in the activation of TLR4-associated adapter proteins MyD88 and TRAK, which promotes the formation of the NF-kB-p65/p50 heterodimer and the activation of the transcription of NF-kB-p65/p50-dependent genes, including a number of factors of the acute inflammatory phase (TNF $\alpha$, IL-1 $\beta$, IL-6, IL-12p40, COX2) [6-9].

An alternative way of Mph activation is mediated by the action of cytokines IL-4/IL-13 or IL10 on surface receptors IL-4R $\alpha /$ IL-13R $\alpha 1$ or IL-10R, respectively. Due to the activation of the corresponding signaling pathways, TFs STAT6 or STAT3/NF-kB-p50/p50 are expressed and translocated into the nucleus, which determines the direction of Mph polarization toward M2 phenotype [10].

Mph polarization is accompanied not only by altered gene transcription, but also by a rearrangement of metabolic pathways and a change in the profile of Mph-secreted factors. The marker of M1/M2 Mph polarization by their metabolic activity can be the peculiarities of L-arginine catabolism. In particular, as a result of L-arginine catabolism in M1 macrophages, the formation of NO and citrulline with the involvement of the NOS2 enzyme is observed [11, 12]. In M2 macrophages L-arginine catabolism leads to ornithine and urea production due to arginase activation. Thus, the secreted NO to arginase ratio (NO/Arg) indicates the state of M1/M2 polarization of Mph [13].

An important feature of $\mathrm{Mph}$ is their high plasticity, ability to change the functional properties and direction of polarization under the influence of microenvironmental signals. M2 Mph exert especially high plasticity that allows to assume a possibility of their repolarization in M1 macrophages by means of immunotherapy. Lectins as substances with immunomodulatory and antitumor properties attract special attention. These glycoproteins are able to selectively bind carbohydrates and carbohydrate components of glycoconjugates of various origins. Highly specific binding of lectins to the corresponding receptors on plasma membranes of cells mediates their cytotoxic or stimulating influence. The mechanisms of antitumor activity of lectins are associated with both direct cytotoxic effects on tumor cells and with indirect effects due to the modulation of immune responses [14-16]. Up-to-date the properties of plant lectins are described in detail, but all currently known plant lectins are quite toxic substances, causing the cytotoxic effect not only on tumor cells but also cells of healthy tissues. Lectins, produced by bacteria, have been studied to a much lesser extent. However, given their low toxicity, bacterial lectins may be considered promising as agents with antitumor and immunomodulatory properties.

The aim of the study was to investigate the effects of lectin from B. subtilis IMV B-7724 on the state of polarization of Mph of intact Balb/c mice.

\section{Materials and methods}

\section{1. Bacterial lectin}

The lectin was produced by spore-forming gram-positive saprophytic bacteria of $B$. subtilis IMV B-7724 (deposited in the collection of the DK Zabolotny Institute of Microbiology and Virology of the National Academy of Sciences of Ukraine, Kyiv) [17]. Lectin was obtained from the culture fluid of the microorganism as described in [18]. After purification and lyophilization, the substance is stored in powder form at $-20^{\circ} \mathrm{C}$. 


\section{2. Animals}

The study has been carried out on male Balb/c mice 2-2.5 month old weighting 19-20 g, bred at the vivarium of R.E. Kavetsky Institute of Experimental Pathology, Oncology and Radiobiology (IEPOR).

The use and care of experimental animals have been performed in accordance with the European Convention for the Protection of Vertebrate Animals Used for Experimental and Other Scientific Purposes [19]. The work was approved by Institutional Animal Care and Use Committee.

\section{3. Isolation and cultivation of macrophages}

Mice were euthanized, and $3 \mathrm{ml}$ of ice-cold PBS, supplemented with heparin (5 U/ml), was injected into the abdomen. The fluid was withdrawn and the abdomen was washed twice with the same volume of heparin-containing PBS. The resulted cells suspension was centrifuged (550 $\mathrm{g}$ for $10 \mathrm{~min}$ ), and the cell pellet was resuspended in $1 \mathrm{ml} 0.9 \% \mathrm{NaCl}$ solution, supplemented with $2.0 \%$ penicillin-streptomycin. These peritoneal exudate cells were counted and cultured in 96-wells flat bottomed plates for $2 \mathrm{~h}\left(37{ }^{\circ} \mathrm{C}, 5 \% \mathrm{CO}_{2}, 100 \%\right.$ humidity). After that non-adherent cells were removed, and the adherent cells were washed two times with $0.9 \% \mathrm{NaCl}$ and taken for further investigation.

In all subsequent studies, Mph were cultured at $37{ }^{\circ} \mathrm{C}$ in a humidified atmosphere with $5 \%$ $\mathrm{CO}_{2}$ in the complete culture medium (RPMI 1640 ("SIGMA", USA), $10 \%$ fetal calf serum (FCS), ("SIGMA", USA), and $40 \mu \mathrm{g} / \mathrm{ml}$ gentamicin.

\section{4. Design of experiment}

Firstly, the in vitro sensitivity of peritoneal $\mathrm{Mph}$ of intact Balb/C mice to different concentrations of the lectin $(2.0 ; 1.0 ; 0.5 ; 0.2 ; 0.1 ; 0.05 ; 0.02 \mathrm{mg} / \mathrm{ml}))$ was assessed.

The assessment of the functional state of Mph was determined by the ratio of NO production levels to arginase activity, as well as by determining the expression levels of STAT-1 and STAT-6 mRNAs by qRT-PCR.

In all experiments, the corresponding indices of $\mathrm{Mph}$, not exposed to stimuli, served as a control.

\section{5. Analysis of cytotoxic action of the lectin}

The Mph suspension was placed into 96-well plates at a concentration of $1 \times 10^{5}$ cells/well in $100 \mu \mathrm{l}$ of the complete growth medium. Lectin was added to the appropriate wells in concentrations of $2 ; 1 ; 0.5 ; 0.2 ; 0.1 ; 0.05$ and $0.02 \mathrm{mg} / \mathrm{ml}$, and cells cultivation continued under standard conditions for 2 or 24 hours. Wells with the culture medium and cells, to which no lectin was added, were used as controls. All samples were analyzed in triplicates. Further evaluation of the cytotoxic effect was performed using the colorimetric MTT test as described in [20].Optical density was measured at $\lambda=545 \mathrm{~nm}$ vs $\lambda=630 \mathrm{~nm}$ with a MicroELISA reader (StatFax-2100, USA). Each sample was measured in triplicate.

Cytotoxic Activity Index (CTAI, \%) was calculated as follows:

$$
\mathrm{CTAI}=\left[1-\left(O D_{\mathrm{Mph}+1}-O D_{\mathrm{Mph}}\right) / O D_{\mathrm{Mph}}\right] \times 100 \% \text {, }
$$

where $O D_{\mathrm{Mph}}$ - optical density of wells, in which only Mph were incubated; $O D_{\mathrm{Mph}+1}$ - optical density of wells, in which Mph were incubated with the lectin.

\section{6. In vitro reprogramming of macrophages}

To polarize the Mph of intact mice toward the M1 phenotype, IFN- $\gamma(20 \mathrm{ng} / \mathrm{ml}$, U-Cytech, the Netherlands) in combination with LPS (100 $\mathrm{ng} / \mathrm{ml}$, Sigma, USA) was added in the complete culture medium; for polarization toward the M2 phenotype, IL-4 was used (10 ng/ml, Sigma, USA). The incubation continued for 24 hours.

\section{7. Measurement of NO production}

NO production was measured by the standard Griess reaction [21]. In brief, cell suspensions $\left(2 \cdot 10^{5}\right.$ cell/well $)$ were placed in a volume of $200 \mu \mathrm{l}$ in 96 -well flat-bottom tissue culture plates and cultured for 24 hours. Each cell culture was investigated in duplicate. At the end of the incu- 
bation period, supernatants were collected and NO production was assessed by the accumulation of nitrite (as stable metabolite of NO) by the Griess reaction. An aliquot of the culture supernatant $(100 \mu \mathrm{l})$ was mixed with an equal volume of the Griess reagent (Acros Organics, Belgium) and incubated for 1 hour at room temperature in the dark. The reaction products were colorimetrically quantified at $\lambda=550 \mathrm{~nm}$. The standard curve, plotted by the results of measurements of the solutions, containing known concentration of $\mathrm{NaNO}_{2}$, was used for converting the absorbance to micromolar concentrations of $\mathrm{NO}$, expressed in $\mu \mathrm{M} \mathrm{NO}_{2}-$ per $10^{6}$ cells.

\section{8. Measurement of arginase activity}

Arginase (Arg) activity was determined based on urea measurement [21]. Mph were lysed by double freezing and melting. Then $50 \mu \mathrm{l}$ of $50 \mathrm{mM}$ Tris- $\mathrm{HCl}(\mathrm{pH} 7.4)$ and $10 \mu \mathrm{l}$ of $50 \mathrm{mM} \mathrm{MnCl}_{2}$ were added to each sample. Samples were heated at $56^{\circ} \mathrm{C}$ for $10 \mathrm{~min}$, and upon addition of $100 \mu \mathrm{l}$ of 0.5 $\mathrm{M}$ L-arginine ( $\mathrm{pH} 9.7)$, heated for further $30 \mathrm{~min}\left(37^{\circ} \mathrm{C}\right)$. The reaction was stopped with $800 \mu \mathrm{l}$ of the acidic mixture $\left(1: 3: 7,96 \% \mathrm{H}_{2} \mathrm{SO}_{4}: 85 \% \mathrm{H}_{3} \mathrm{PO}_{4}: \mathrm{H}_{2} \mathrm{O}\right)$. Then $40 \mu \mathrm{l}$ of $\alpha$-isonitrosopropriophenone (Sigma-Aldrich) was added to the solution, which was heated for $30 \mathrm{~min}\left(95^{\circ} \mathrm{C}\right)$ and incubated for 30 min at $4{ }^{\circ} \mathrm{C}$. The urea concentration was measured spectrophotometrically at $\lambda=550 \mathrm{~nm}$. Values of optical density were converted to the mass of urea based on the calibration curve of the standard urea solution. Arg activity was calculated as described in [22]. One unit of Arg activity means the amount of the enzyme, hydrolyzing $1 \mu \mathrm{M}$ of arginine per $1 \mathrm{~min}$. The results are expressed as units $/ 10^{6}$ cells.

\section{9. qRT-PCR}

Total RNA was isolated from $2 \times 10^{5}$ Mph using NucleoZOL (MACHEREY-NAGEL GmbH \& Co. KG, Germany) according to the manufacturer's protocol. cDNA synthesis was performed using RevertAid Reverse Transcriptase, RiboLock Inhibitor, dNTP mix and Oligo(dT) primer (Thermo Scientific, USA). qRT-PCR was held on sequence detection system 7500 (Applied Biosystems, CA, USA) using Maxima SYBR Green/ROX qPCR Master Mix (Thermo Scientific, USA) and following forward (For) and reverse (Rev) list of primers: STAT1 For 5'-TCCTTCTGGCCTTGGATTGA-3', Rev 5'-ACCGTTCCACCCATGTGAA-3', STAT6 For 5'-AGATGAGGCTTTCCGGAGTCA-3', Rev 5'-CCCATATCTGAGCTGAGTTGCA-3`, TBP For 5'-CCAATGACTCCTATGACCCC-3’, Rev 5'-GTTGTCCGTGGCTCTCTTATTC-3'. The target genes' Ct values were normalized to $\mathrm{Ct}$ value of the internal control gene (TBP) using ddCt method.

\section{10. Statistical analysis}

The statistical significance was evaluated by the nonparametric Mann-Whitney U test, and the correlation analysis was determined according to Spearman's correlation using Prism software Version 8.0. The statistical significance between examined groups was assessed as $p<0.05$.

\section{Results and discussion}

First of all, the toxic in vitro effect of lectin from B. subtilis IMV B-7724 on the peritoneal $\mathrm{Mph}$ of intact Balb/c mice was evaluated. It is shown, that the studied lectin has a concentration-dependent cytotoxic effect (Table 1).

Table 1

Cytotoxic activity (CTAI, \%) of lectin from B. subtilis IMV B-7724 against Mph of intact Balb/c mice

\begin{tabular}{ccc}
\hline \multirow{2}{*}{ Concentration of the lectin, $\mathbf{~ m g / m l}$} & \multicolumn{2}{c}{ Cytotoxic activity ( \%) after incubation for } \\
\cline { 2 - 3 } & $\mathbf{2}$ hours & $\mathbf{2 4}$ hours \\
\hline 2.0 & $86.1 \pm 1.6$ & $85.0 \pm 2.1$ \\
1.0 & $82.1 \pm 2.1$ & $80.1 \pm 0.9$ \\
0.5 & $60.4 \pm 3.9$ & $75.8 \pm 2.4$ \\
0.2 & $54.4 \pm 5.1$ & $60.5 \pm 1.3$ \\
0.1 & $25.4 \pm 6.9$ & $21.9 \pm 4.7$ \\
0.05 & 0 & 0 \\
0.02 & 0 & 0
\end{tabular}


The cytotoxic effect of the lectin was observed when it is used in concentrations from 0.1 to $2.0 \mathrm{mg} / \mathrm{ml}$. The calculation of the $\mathrm{IC}_{50}$ (concentration of an agent that is required for killing of $50 \%$ target cells in vitro) showed that the cytotoxic effect did not depend on the duration of exposure to the lectin. The $\mathrm{IC}_{50}$ after $2 \mathrm{~h}$ of incubation of macrophages with lectin was $0,155 \mathrm{mg} / \mathrm{ml}$; after $24 \mathrm{~h}$ of incubation $-0,148 \mathrm{mg} / \mathrm{ml}$. The incubation with lectin at lower doses $(0.05$ and $0.02 \mathrm{mg} / \mathrm{ml})$ had no cytotoxic effect on macrophages. Taking into account the obtained results, for further studies we have chosen the lowest concentrations of the lectin $(0.05$ and $0.02 \mathrm{mg} / \mathrm{ml})$.

The effect of the lectin on the polarization of Mph was evaluated by calculating the NO/Arg ratio. When Mph were exposed to LPS in combination with IFN $\gamma$, a 1.3-fold increase in the NO/Arg ratio was observed compared to the intact control (Fig. 1), which is characteristic of the M1 phenotype. In contrary, the action of IL-4 resulted in a significant decrease in the NO/Arg ratio compared to the intact control (1.9 times), which indicated the predominance of arginase activity in the metabolism of L-arginine and is a feature of the M2 phenotype. The obtained results correlate with the literature on the possibility of changing the direction of the Mph polarization by the influence of LPS+IFN $\gamma$ and IL-4 [10, 11].

The addition of lectin at a concentration of $0.02 \mathrm{mg} / \mathrm{ml}$ to the culture medium of macrophages led to a significant increase in NO production and a decrease in Arg activity. The NO/Arg ratio increased 1.4 times as compared with the intact control (18.6 a.u. vs 13.5 a.u.) and approached this indicator under the combined action of LPS + IFN $\gamma$ (18.1 c.u.)

The incubation of Mph with lectin at a concentration of $0.05 \mathrm{mg} / \mathrm{ml}$ had no effect of the $\mathrm{NO} /$ Arg ratio compared to that in the intact control (14.2 vs 13.5). Instead, increasing the concentration of lectin up to $0.2 \mathrm{mg} / \mathrm{ml}$ caused downregulation in macrophages activity that reflects in 1.3 -fold decrease in the NO/Arg ratio compared to the intact control (10.5 a.u. vs 13.5 a.u.) (Fig. 1).

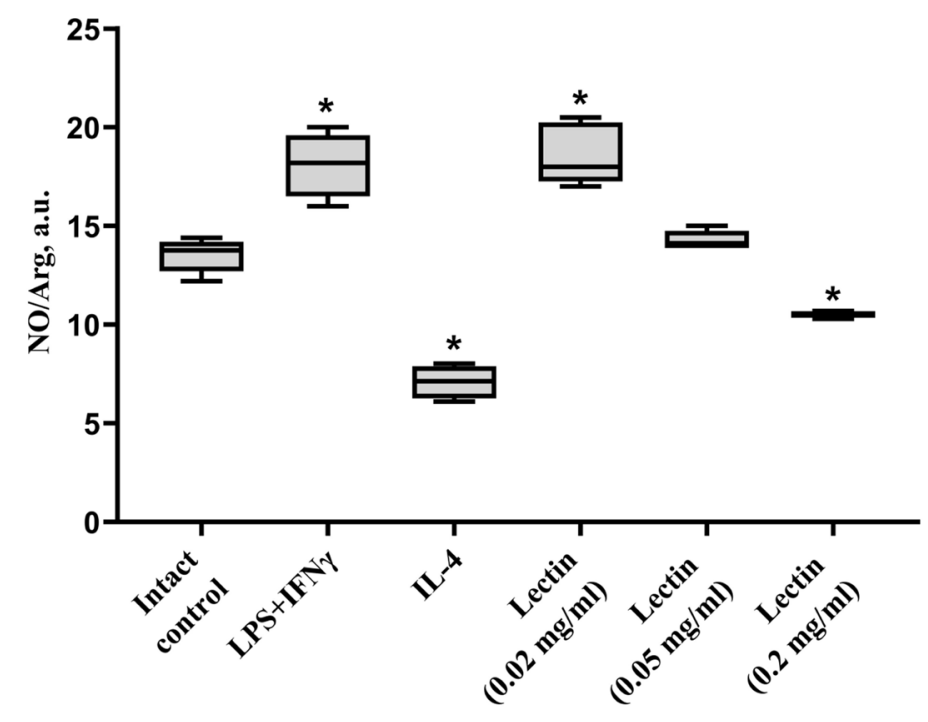

Fig. 1. Changes in the NO/Arg ratio under the action of different stimuli on the Mph of intact $\mathrm{Balb} / \mathrm{c}$ mice; ${ }^{*}-p<0.05$ compared with the intact control

Given into account the results obtained, we have decided to focus our further research on LPS+IFN- $\gamma$, lectin $(0.02 \mathrm{mg} / \mathrm{ml})$ and lectin $(0.05 \mathrm{mg} / \mathrm{ml})$ 's effect om Mph and to study whether the mechanisms of their action are also similar.

We have evaluated the mRNA expression levels of STAT1 and STAT6 in all experimental groups, as far as this TFs are known regulators of Mph polarization into M1 or M2 phenotypes, respectively.

STAT1 mRNA expression levels in Mph after their co-coutivation with LPS+IFN- $\gamma$ and lectin in concentration $0.02 \mathrm{mg} / \mathrm{ml}$ were significantly higher compared to the intact control 1.52 a.u. and 1.75 a.u. vs 1 a.u., respectively (Fig. 2, a). Instead, the influence of lectin in con- 
centration $0.05 \mathrm{mg} / \mathrm{ml}$ did not cause the changes in STAT1 mRNA expression level. As expected, we did not observe any difference in the STAT6 mRNA expression level after the application of LPS + IFN- $\gamma$ and lectin in both concentrations because this TF is involved in M2 polarization not at M1 (Fig. 2, b).
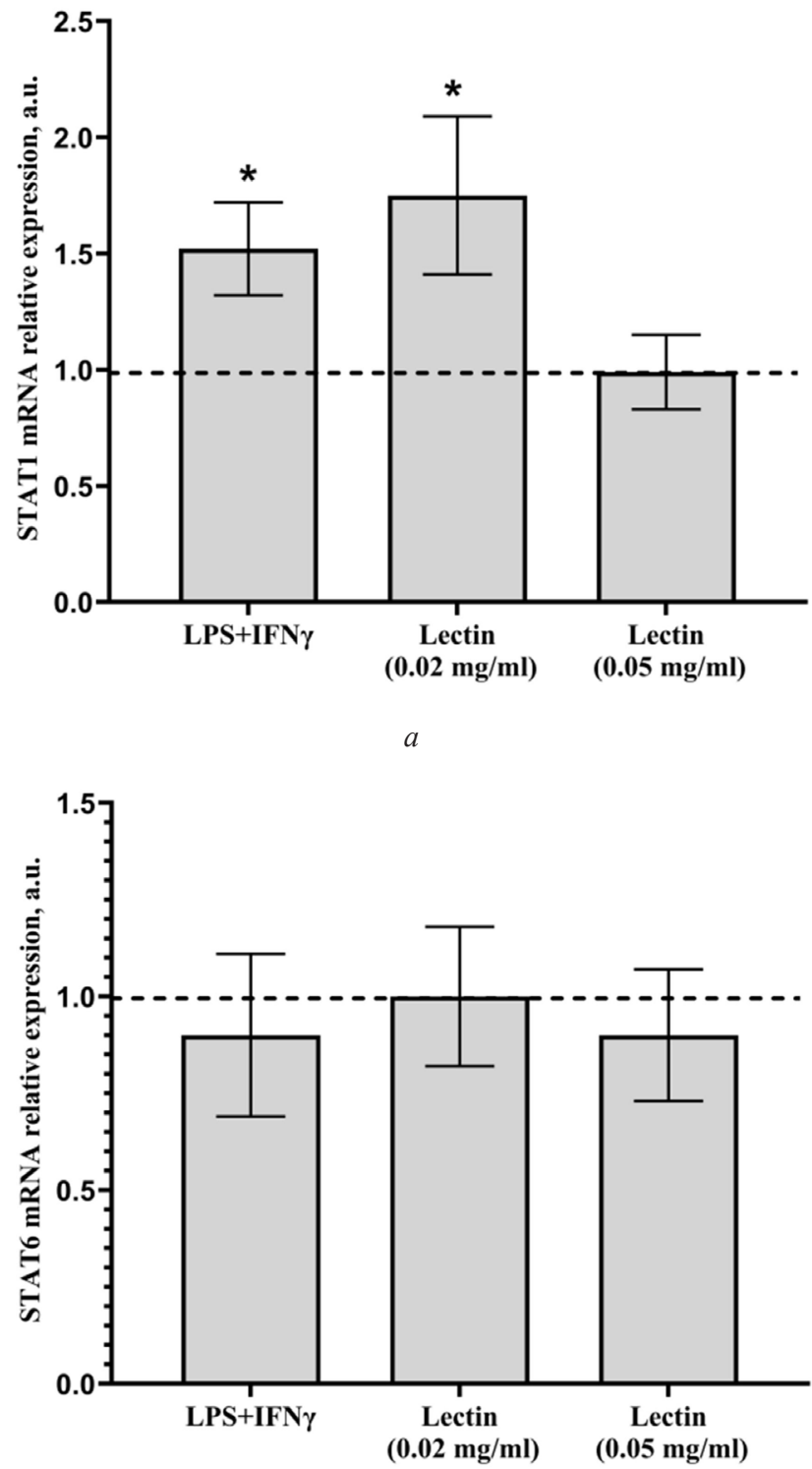

$b$

Fig. 2. mRNA expression levels after co-cultivation of Mph with various stimuli: $a$ - STAT1;

$$
b \text { - STAT6; - - - - - the intact control; }
$$

$* p<0.05$ compared with the intact control

Similar to the NO/Arg index, the analysis of the ratio of the expression level of STAT1 mRNA to the expression level of STAT6 mRNA (STAT1/STAT6 ratio) allows to assess the state of M1/M2 polarization. The combined effect of LPS+IFN- $\gamma$ as well as lectin in concentration $0.02 \mathrm{mg} / \mathrm{ml}$ but not in concentration $0.05 \mathrm{mg} / \mathrm{ml}$ led to a significantly increase of the STAT1/STAT6 ratio compared to the intact control and were similar to those, observed in NO/ Arg ratio (Fig. 3). 


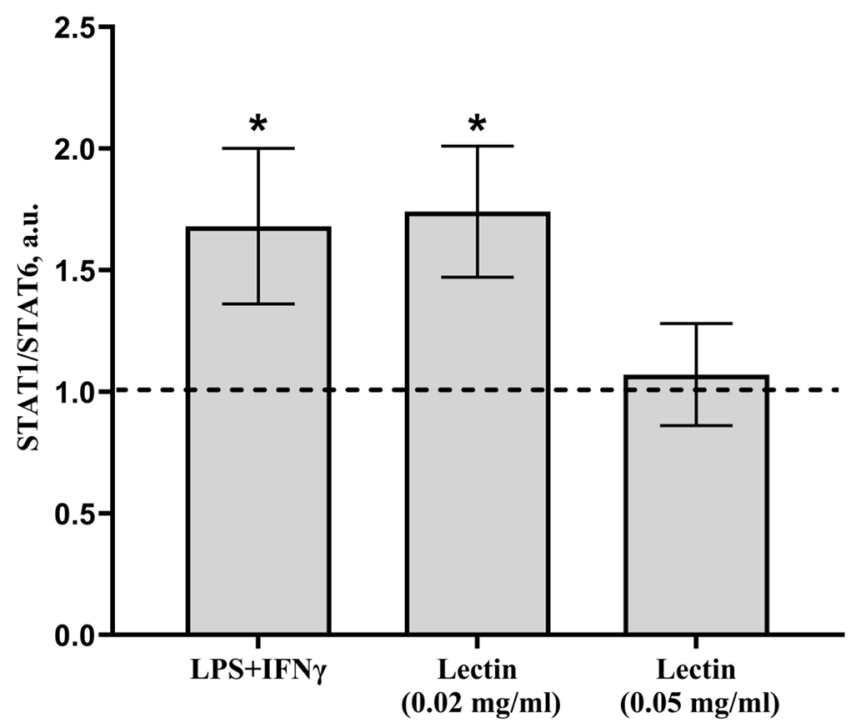

Fig. 3. STAT1/STAT6 ratio in Mph under the action of different stimuli. _ - _ - - the intact control; * $p<0.05$ compared with the intact control

Our results are consistent with the literature on the study of molecular mechanisms of Mph activation. In particular, it is known, that the action of IFN- $\gamma$ and/or LPS in Mph cause up-regulation of the NOS2 enzyme expression (via STAT1-dependent pathway), which metabolizes L-arginine to NO and citrulline and is characteristic for the M1 phenotype. Under the action of IL-4, the expression of the enzyme arginase, which hydrolyzes L-arginine to ornithine and urea, increases, which is a characteristic functional feature of the formation of a subpopulation of cells with M2 phenotype [10, 11]. Therefore, when Mph are polarized in the M1 direction, there is a shift in the NO/Arg ratio toward an increase in NO production, probably due to the increased NOS2 expression and decreased arginase activity. The detected changes in the metabolic activity of peritoneal Mph of intact mice under the influence of low concentrations of bacterial lectin may be caused by the changes in the expression of TFs of the signaling pathway JAK-STAT. This evidence opens the prospects for studying the mechanism of action of the lectin as a means of mediating the increased antitumor immune response.

\section{Conclusions}

1. The effect of lectin from B. subtilis IMV B-7724 on the peritoneal Mph of intact the Balb/c mice in vitro is concentration-dependent: $\geq 0.1 \mathrm{mg} / \mathrm{ml}$ - cytotoxic; 0.02 and $0.05 \mathrm{mg} / \mathrm{ml}-$ stimulating (in terms of functional activity).

2. Under the action of low concentrations of the lectin there is observed a significant increase in the NO/Arg ratio, which is characteristic of Mph with the M1 phenotype.

3. Changes in the STAT1 mRNA expression under the influence of the lectin in concentration $0.02 \mathrm{mg} / \mathrm{ml}$ on $\mathrm{Mph}$ are similar to the changes under combined action of LPS and IFN- $\gamma$.

\section{Conflicts of interest}

The authors declare no conflicts of interest.

\section{References}

[1] Pan, C., Liu, H., Robins, E., Song, W., Liu, D., Li, Z., Zheng, L. (2020). Next-generation immuno-oncology agents: current momentum shifts in cancer immunotherapy. Journal of Hematology \& Oncology, 13 (1). doi: https://doi.org/10.1186/s13045020-00862-w

[2] Potebnya, G. P., Lisovenko, G. S. (2010). Biotherapy of cancer: achievements and perspectives. Oncology, 12 (3), $237-243$. Available at: http://dspace.nbuv.gov.ua/handle/123456789/19725

[3] Ryspayeva, D. E., Ponomarova, O. V., Lisovska, N. Y. (2018). Immunotherapy is the first line of advanced lung cancer: what is new in 2018. Clinical oncology, 8 (2 (30)), 92-96. Available at: http://nbuv.gov.ua/UJRN/klinonk_2018_8_2_4 
[4] Mills, C. D., Lenz, L. L., Harris, R. A. (2016). A Breakthrough: Macrophage-Directed Cancer Immunotherapy. Cancer Research, 76 (3), 513-516. doi: https://doi.org/10.1158/0008-5472.can-15-1737

[5] DeNardo, D. G., Ruffell, B. (2019). Macrophages as regulators of tumour immunity and immunotherapy. Nature Reviews Immunology, 19 (6), 369-382. doi: https://doi.org/10.1038/s41577-019-0127-6

[6] Hörhold, F., Eisel, D., Oswald, M., Kolte, A., Röll, D., Osen, W. et. al. (2020). Reprogramming of macrophages employing gene regulatory and metabolic network models. PLOS Computational Biology, 16 (2), e1007657. doi: https://doi.org/10.1371/ journal.pcbi.1007657

[7] Huang, X., Li, Y., Fu, M., Xin, H.-B. (2018). Polarizing Macrophages In Vitro. Methods in Molecular Biology, $119-126$. doi: https://doi.org/10.1007/978-1-4939-7837-3_12

[8] Wang, N., Liang, H., Zen, K. (2014). Molecular mechanisms that influence the macrophage M1-M2 polarization balance. Frontiers in Immunology, 5. doi: https://doi.org/10.3389/fimmu.2014.00614

[9] Piaszyk-Borychowska, A., Széles, L., Csermely, A., Chiang, H.-C., Wesoły, J., Lee, C.-K. et. al. (2019). Signal Integration of IFN-I and IFN-II With TLR4 Involves Sequential Recruitment of STAT1-Complexes and NFאB to Enhance Pro-inflammatory Transcription. Frontiers in Immunology, 10. doi: https://oi.org/10.3389/fimmu.2019.01253

[10] Murray, P. J., Allen, J. E., Biswas, S. K., Fisher, E. A., Gilroy, D. W., Goerdt, S. et. al. (2014). Macrophage Activation and Polarization: Nomenclature and Experimental Guidelines. Immunity, 41 (1), 14-20. doi: https://doi.org/10.1016/j.immuni.2014.06.008

[11] Bronte, V., Zanovello, P. (2005). Regulation of immune responses by L-arginine metabolism. Nature Reviews Immunology, 5 (8), 641-654. doi: https://doi.org/10.1038/nri1668

[12] Karaman, O. M., Ivanchenko, A. V., Chekhun, V. F. (2019). Macrophages - a perspective target for antineoplastic immunotherapy. Experimental Oncology, 41 (4). doi: https://doi.org/10.32471/exp-oncology.2312-8852.vol-41-no-4.13698

[13] Brüne, B., Courtial, N., Dehne, N., Syed, S. N., Weigert, A. (2017). Macrophage NOS2 in Tumor Leukocytes. Antioxidants \& Redox Signaling, 26 (18), 1023-1043. doi: https://doi.org/10.1089/ars.2016.6811

[14] Yau, T., Dan, X., Ng, C., Ng, T. (2015). Lectins with Potential for Anti-Cancer Therapy. Molecules, 20 (3), $3791-3810$. doi: https://doi.org/10.3390/molecules20033791

[15] Protivoopuholevye svoystva lektinov omely beloy. Available at: http://www.oncology.ru/specialist/journal_oncology/ archive/0111/006/

[16] Mazalovska, M., Kouokam, J. C. (2020). Plant-Derived Lectins as Potential Cancer Therapeutics and Diagnostic Tools. BioMed Research International, 2020, 1-13. doi: https://doi.org/10.1155/2020/1631394

[17] Chekhun, V. F., Didenko, H. V., Cheremshenko, N. L., Kruts, O. O., Bazas, V. M., Voieikova, I. M. et. al. (2018). Pat. No. 131824 UA. Shtam bakteriy Bacillus subtilis IMB B-7724 - produtsent tsytotoksychnykh rechovyn z protypukhlynnoiu dieiu. No. u201809697; declareted: 27.09.2018; published: 25.01.2019, Bul. No. 2.

[18] Pidhorskii, V. S., Kovalenko, E. O., Symonenko, I. O., Lakhtyn, V. M. (1988). Pat. No. 1791 UA. The method for the obtainmen of bacterial lectin, specific to sialic acids. No. 4471130/13; declareted: 01.08.1988; published: 23.01.1991, Bul. No. 3.

[19] Kozhemiakin, Yu. M., Khromov, O. S., Filonenko, M. A., Saifetdinova, H. A. (2002). Naukovo-praktychni rekomendatsiyi z utrymannia laboratornykh tvaryn ta roboty z nymy. Kyiv: Avitsena, 155.

[20] Wilson, A. P. (2000). Cytotoxicity and viability assays in animal cell culture: A practical approach. Oxford University Press, 165.

[21] Reiner, N. E. (Ed.) (2009). Macrophages and dendritic cells. Methods and Protocols. Humana Press, 368. doi: https:// doi.org/10.1007/978-1-59745-396-7

[22] Dovgiy, R. S., Shitikov, D. V., Pishel, I. N., Opeida, E. V., Skivka, L. M. (2015). Functional state and metabolic polarization of splenic macrophages of old immunized mice. Problemy stareniya i dolgoletiya, 24 (2), 144-152. Available at: http:// geront.kiev.ua/library/psid/2015-2.pdf

How to cite: Chumak, A., Shcherbina, V., Fedosova, N., Chekhun, V. (2021). Polarization of macrophages of mice under the influence of lectin from Bacillus subtilis IMV B- 7724. EUREKA: Life Sciences, 3, 3-10, doi: https://doi.org/10.21303/2504-5695.2021.001878 


\title{
INFLUENCE OF PHILAZONIT BIOPREPARATION ON THE MYCOBIOME OF SOYBEAN PLANTS RHIZOSPHERE
}

\author{
Alla Parfenuk \\ Doctor of Biological Sciences, Professor ${ }^{l}$ \\ vereskpar@ukr.net \\ Liliia Havryliuk \\ Graduate student ${ }^{1}$ \\ 410agroeco@gmail.com \\ Irina Beznosko \\ PhD in Biological sciences ${ }^{l}$ \\ beznoskoirina@gmail.com \\ Larisa Pasichnik \\ PhD in Agricultural Sciences \\ National University of Life and Environmental Sciences of Ukraine \\ 15 Heroes of Defense str, Kyiv, Ukraine, 03041 \\ pasichnik@ukr.net \\ Yuliia Turovnik \\ Graduate student \\ turovnikylia@gmail.com \\ Yuri Ternovyi \\ Candidate of Agricultural Sciences \\ Skvyra Research Station of Organic Production of the Institute of Agroecology and Environmen- \\ tal Management of NAAS \\ 1 Selection str, Skvyra, Ukraine, 09001 \\ ternowoj@i.ua \\ ${ }^{1}$ Institute of Agroecology and Environmental Management of NAAS \\ 12 Metrologichna str, Kyiv, Ukraine, 03143
}

\begin{abstract}
The article presents the results of analysis of biodiversity and spatial-functional structure of the microbial complex in the soil rhizosphere, and development of ways to regulate the number of phytopathogenic micromycetes in the rhizosphere of soybean plants in organic production. Varieties of plants of soy were grown using the biopreparation «Philazonit", which was developed in the company "Philazonit of Ukraine". The study determined the effect of phylazonite biopreparation on the mycobiome of the rhizosphere of soybean plants. The interaction of plants of soy varieties Kent and Suzir'ja with phytopathogenic micromycetes in conditions of the organic production in the Central Forest-Steppe of Ukraine (Research farm "Skvyrske" of Institute of Agroecology and Nature Management of the National Academy of Agrarian Sciences of Ukraine (IANM of the NAAS) was investigated. The number of phytopathogenic micromycetes in the rhizosphere of plants of different varieties of soy is determined depending on the variety and technology of its cultivation. It was established that the biopreparation Philazonit inhibits the formation of the number of phytopathogenic micromycetes in the rhizosphere of plants of the soy variety Suzir'ja and Kent during the growing season. It is proved that the representatives of genera: Alternaria, Fusarium, Penicillium, Aspergillus are dominated in the rhizosphere of plants of soy of both varieties. In the rhizospheres of plants of the soy Suzir'ja variety the representatives of genus Penicillium (32.8\%) most often occurred. The smallest number of micromycetes were members of the genus Aspergillus (9.5\%). In the rhizosphere of plants of the Kent variety dominated by representatives of the genera Alternaria and Fusarium (35.6\% and $34.1 \%$ respectively). Representatives of the genus Penicillium were $15 \%$ and Aspergillus - $15.3 \%$ It is proved noted that during the studies there was a
\end{abstract}

